\title{
Innovation and the public service: achieving inclusive service delivery
}

Working paper

Paul Plantinga, Human Sciences Research Council

pplantinga@hsrc.ac.za

\begin{abstract}
Innovation is seen as a way for the public sector to improve performance and reduce costs. This is particularly attractive for developing countries in which large parts of the population do not have access to quality basic services. In response, innovation readiness assessments are being implemented and innovation units have been established, all of which seek to develop an innovation 'culture' in government. However, the growing pressure for public officials to adopt an innovation mindset can create tensions with existing processes and 'bureaucratic' practices. Through a case study of South Africa's state-owned enterprises, municipalities, sector departments and public innovation intermediaries, this paper argues that a more nuanced view is needed of the diverse actors, roles and activities that do (and could) support public sector innovation, which includes various enabling bureaucratic activities. Each of these entities contributes specific legitimacies and capacities to innovation processes, based on underlying values, which can be better recognised and supported to achieve sustainable innovation outcomes and more inclusive service delivery.
\end{abstract}

Keywords: Innovation, public administration, inclusive development, South Africa

\section{Introduction}

In many countries there is a drive to accelerate innovation within government as a way to improve the quality of service delivery and reduce costs (Drechsler and Karo 2017; Petersen and Kruss 2019; Vivona, Demircioglu, and Raghavan 2021). This is seen as part of a more fundamental change in the types of skills and capabilities public servants need to address the complexity of social challenges arising from a volatile, uncertain, complex and ambiguous or 'VUCA' world (van der Wal 2017; Sørensen and Torfing 2012; Voegtlin and Scherer 2017). Amongst others, this skill set includes a collaborative mindset, emotional intelligence, data centricity and a 'tech savvy' way of working (Vivona, Demircioglu, and Raghavan 2021). Collaboration, openness, end-user participation and a more systemic approach are all central to the way innovation is expected to take place, especially if it is to be sustainable and inclusive (Daniels et al. 2020; Chataway et al. 2017)

However, as several studies from South Africa conclude, the adoption of these practices depends on enablers in the wider institutional and organisational environment, to build trust in and support implementation of innovation interventions. These enablers include reducing red tape, ensuring sufficient political support and addressing corruption (Biljohn and Lues 2019, 143; Petersen and Kruss 2019; Ndabeni, Rogerson, and Booyens 2016; Senyolo et al. 
2018; Hart, Booyens, and Sinyolo 2020; Jacobs et al. 2019; Mosiea et al. 2018). At a deeper level, many commentators argue that bureaucracy is incompatible with innovation. Part of this view is probably true and, in South Africa, exacerbated by challenges with state capacity. Various policy documents acknowledge an erosion of professional skills and weak embodiment of constitutional values within government (NSG 2020, 43-49), all of which suggests that there is limited potential for embracing some of the principles or practices that could support collaboration and co-creation.

The public sector challenge of limited individual and organisational capacity and legitimacy related to innovation is not unique to South Africa (Drechsler and Karo 2017). Whilst many public entities have sought to foster a 'culture' of innovation which values new ideas, diverse relationships and open interactions - along with novel incentive and organisational structures - the reality is that innovation initiatives can lead to tensions in operational environments around who should be innovating and how innovation activities relate to traditional performance measures and daily responsibilities (Hart, Booyens, and Sinyolo 2020). As a change management process, adopting an innovation culture often requires more 'reform than [the organisation] and staff can bear' (van der Wal 2017, 149).

To achieve more sustainable innovation, this paper aims to better understand the diverse roles that public officials are playing within their organisations, and the different capacities and legitimacies that they can contribute towards positive innovation outcomes (Karo and Kattel 2016a; van der Wal 2017). A key starting point is to consider what types of innovation are being recognised and pursued, and the underlying goals and values that shape innovation priorities and approaches.

\section{Public sector innovation and diverse capabilities}

From a review of over 180 articles and books de Vries, Bekkers and Tummers (2016) identify a range of public sector innovation types, from service and product innovation, to governance and conceptual innovation. To this list, van der Wal adds rhetorical innovation: the creative ways in which government convinces stakeholders that it is up-to-date and 'reform is under way' $(2017,141)$. In all these forms of innovation, the state is seeking certain goals. Although much of the emphasis has been on efficiency or "performing with less' in providing services to customers, usually by adopting practices associated with New Public Management (NPM) (Osborne, Radnor, and Nasi 2013; Hood 1991; Thomas 2013), de Vries, Bekkers and Tummers find that there is also a strong emphasis on goals related to participation and cooperation, and the logic of appropriateness. Appropriateness means that citizens trust that government will address issues they are concerned about $(2016,155)$. Trust depends on a sense that government is responsive to citizen needs and that they retain democratic influence over what services are provided and how.

This view of the public as democratically-engaged citizen or even a partner, rather than as simply a customer, is mainly relevant to more complex issues and services for which there are potentially unintended consequences and potential for bias, and which need to be 
addressed through collective decision-making methods (Thomas 2013). Osborne, Radnor and Nasi (2013) go further in arguing that co-production is inherent to what the public service is: much of what the state provides is a service, and services are distinct from products in that they are a process or 'performance', not a thing that is delivered (Thomas 2013, 788). A service therefore requires participation, through iterations of feedback and adjustment to elicit the tacit or 'sticky' knowledge of users (Osborne, Radnor, and Nasi 2013, 146). By valuing user feedback and scanning the 'margins' of society for ideas, there is more potential for innovation (Mulgan and Albury 2003). Importantly, however, partnering and coproduction can lead to over-customisation and an individualised approach, which can be at odds with the wider 'public as citizen' perspective needed to manage the potentially contradictory demands of stakeholders (Lee 2015). Managing participation and potential conflict about innovation goals and outcomes is particularly important for innovation's relationship to inclusive growth or development, for which authentic engagement by affected individuals and communities in governance processes is critical (OECD 2017; Foster and Heeks 2015).

\section{Diverse capabilities and values}

In seeking to address more complex service delivery needs, there does seem to be a need for cross-sectoral search and facilitation skills, but does this apply to all civil servants? van der Wal argues that different values and capabilities are relevant at different stages of problem solving and innovation (2017, 146-147). For example, in the earlier stages of idea generation and selection, there needs to be more of an emphasis on (and associated capacity for) creative thinking and connecting ideas across boundaries. At later stages of the process, during testing and scaling up, there is a need for managers who can be pragmatic about assessing potential impact, enrolling political support and working with relevant processes or practices to enable embedding and adoption.

This perspective starts to recognise the importance of diverse values and capacities, and has been acknowledged as relevant to the South African context (Booyens et al. 2019, 36). Generally though, there is still a general tendency across practice and research to characterise public sector bureaucrats as 'less motivated' with 'weaker leadership' when compared to private sector equivalents (Vivona, Demircioglu, and Raghavan 2021). As a result, there is a demand for a more 'business-like' (van der Wal 2017, 152) or 'entrepreneurial' orientation that can support an innovation culture and improved performance (Malatjie, Garg, and Rankhumise 2017; Vivona, Demircioglu, and Raghavan 2021).

Getting innovation-capable then involves addressing (and measuring) a number of action areas, from awareness, to structures, processes, infrastructure, skills and leadership; , much of which is oriented towards civil servants becoming less risk-averse and more networked and collaborative in how they go about their day-to-day work (Dutta et al. 2009; Bason 2018; OECD 2019a; Booyens et al. 2019). Whilst these are important considerations for improving public service delivery, there are critical tensions and risks that need to be managed, for 
which a diversity of new and existing capabilities (and supportive values) are needed. For example, as governments look to be more open and technology-enabled, there is a high likelihood that participation becomes biased towards a technical elite, which can lead to the exclusion of other important decision-making stakeholders (Margetts 2011). In addition, government acquisition of innovative products or services is notoriously difficult, and can be at odds with other important values, such as legitimacy and transparency (Plantinga and Adams 2020, 2021). The location and nature of innovation can also lead to distinct risks. Lower-level, enhancement-oriented innovation tends to build on what exists and can therefore neglect those who are currently not benefitting. Meanwhile, higher-level, missionoriented innovation 'can deprioritise other important agendas' and antagonise those who have different values (Ramalingam and Prabhu 2020). In South Africa, relatively intimate methods of co-creation may be feasible in the planning stages of services, but when it comes to delivery, participation can break down (Biljohn and Lues 2019) - especially in the context of large-scale outsourcing of service delivery functions (PARI 2020). For these situations, different skills and forms of engagement may be needed to encourage delivery innovation and improved outcomes, such as arms-length transparency and oversight.

\section{An organisational diversity lens}

Being able to enrol innovation as a useful practice will depend on the adoption of certain new practices, structures and values; whilst also enhancing (and integrating or reconciling with) a diversity of other capabilities and legitimacies. As a framework for understanding this mix of capacities, this paper draws on a mapping developed by Karo and Kattel (2016a; 2016b; 2015) and summarised in Table 1.

[Table 1 near here]

At the centre of this mapping is a set of routines which shape how an organisation uses its resources or capacities to achieve certain innovation goals (similar to those observed in Booyens et al. 2019, 36). Example routines include

- strategic management: e.g., centralised and planned versus decentralised experimentation;

- personnel management: e.g., flexible recruitment and performance management versus standardised human resource (HR) processes;

- financial management: e.g., procedure and compliance-driven versus outcomeoriented and;

- coordination: e.g., the way in which external interactions are organised, more formal versus less formal.

In their analyses, Karo and Kattel place a strong emphasis on how legitimacy is derived, which is significant in the context of widespread scepticism around government involvement in innovation. Legitimacy is shaped by a mix of external narratives, history, religion, culture, and symbols, according to certain value frames (Nabatchi 2018); but also, recursively, by the 
organisation and individual's ability to deliver on the expectations that have been created (Drechsler and Karo 2017). Therefore, rhetorical innovation and innovation narratives (Pedersen and Johansen 2012) need to be supported by impactful process, administrative and technological innovations (van der Wal 2017). As Drechsler and Karo argue, in China, the Mandate of Heaven $(\mathrm{MoH})$ as a historical-religious narrative is a source of legitimacy for public officials involved in innovation work, but this mandate is only sustained as long as officials deliver on expected outcomes and benefits. The mandate creates space and autonomy which are useful for innovation but also pressure for civil servants to design and implement suitable policies to achieve wider goals. This is distinct from the Western approach in which

... the legitimacy of government actions needs to be 'imported' from external symbols and institutions, which may also affect the structuralinstitutional elements of [public administration (PA)] in unexpected ways; in the Confucian context, the MoH may provide an endogenous source of legitimacy for PA, thus allowing it to maintain time-and context-specific structural-institutional elements of PA. ... [Public sector innovation] and innovativeness of civil servants is not about adopting the newest policy and governance approaches, but it is about routine, persistent and purposeful

application and refinement of state-of-the-art knowledge, ideas and procedures on how to deliver the main tasks of the state. Innovativeness of $P A$ and civil servants is equal to their overall performance (Drechsler and Karo 2017, 22-23)

The suggestion is that in China, the focus for public officials involved in innovation is less on novelty as a (compensating) source of legitimacy, and more on demonstrating an improvement in outcomes.

\section{A case study of public sector innovation in South Africa}

\section{Objectives and method}

Many developing countries sit a cross-road of Western, Asian and local public administration philosophies which give rise to distinctive innovation priorities and programmes. Whilst we are likely to find several interesting stories of policy appropriation, success and failure across all of these countries, this paper focuses on South Africa and how the current government has organised itself to support internal innovation. In large part this is because South Africa is at a key point of reflection in how it approaches both innovation and public administration as linked objectives.

The current policy window is framed by at least two important policy events taking place at a national level: First, as of 2019, a new White Paper on Science, Technology and Innovation (STI White Paper) by South Africa's Department of Science and Innovation (DSI) sets out a long term vision for science, research and innovation in the country; which will be realised through a succession of decadal plans. These decadal plans will provide more detailed 
guidance on technology choices and priority initiatives. Nonetheless, the STI White Paper does outline a broad direction based on an 'expanded' NSI and an explicit policy intent to 'Strengthen government's role as an enabler for innovation' (DSI 2019, 41). Second, is an initiative by the Ministry of Public Service and Administration, through the National School of Government (NSG), to develop a National Implementation Framework towards the Professionalisation of the Public Service (NSG 2020) (Draft Professionalisation Framework) and the closely linked view that government should 'strive to be an entrepreneurial state by being more innovative, taking risks' (Ngcobo 2021). Given this convergence of policy interest, now is an interesting time to explore how public sector innovation is being approached within key institutions, and to what extent this reflects the aspirations of the above policy activity.

The following sections present findings from a discourse analysis of textual documents mainly in the form of written public policy, programme, media and primary research material related to government innovation in South Africa. Texts reflect the socio-technical reality of organisational environments but also serve processes of agency and organising (Fairclough 2005). Through an analysis of the above documents, it is possible to map out the emergence, hegemony and operationalisation of discourses as they are enacted by various individuals and groupings in processes of change (and resistance). In this paper, the particular focus is on how globally and (sub)nationally contested ideas around innovation come to influence its adoption and organisation in the South African context. Whilst innovation policy may be visible in the scientific-commercial assemblage of research infrastructures, data, publications and products or services; public understanding of innovation and associated policy interventions is relatively fluid and contested when compared to other sectors - even to information technology, for which the objectives and effects continue to be shaped by ideological debates (Avgerou and Bonina 2020). For this reason, discourse plays a key role in determining how public sector innovation is organised, but also in how the benefits of different approaches are perceived.

The selection of texts and organisations for analysis followed a method used by the OECD in the mid-2000s, when an evolutionary innovation systems lens provided the framework for identifying and analysing the contribution of different organisations to South Africa's innovation capabilities (OECD 2007). For this paper, a similar but more static snapshot is developed for the current public innovation system by focusing on three key groups of organisations shaping public sector innovation, as a specialisation of the policy and intermediary 'sub-system' (Cooke 2008; Moodysson, Trippl, and Zukauskaite 2017).

Specifically, this selection includes categories of organisation that, broadly, cover the majority of public innovation responsibility in the country: (1) Municipalities, provincial governments and national sector departments which are at the centre of policy development, planning and front-line service delivery; (2) State-owned enterprises which are largely responsible for the development and provision of bulk infrastructure and services to municipalities and businesses; and (3) Public sector innovation intermediaries which aim to stimulate innovation in the above entities, and broker relationships with private sector, 
research and non-governmental partners. In each category, a limited number of highervisibility entities have been selected for analysis, because of their relevance to innovation discourse. Moreover, whilst, academia, civil society, the private sector, international agencies and other actors are all relevant to how government innovation takes place, this snapshot aims to provide insights into the views of core government actors working at the intersection of innovation and service delivery.

The texts used for analysis were identified through website searches for and through a variety of documentary sources - from annual reports to parliamentary briefings - to identify comments on the goals, capabilities, legitimacy, routines and organisational form associated with innovation. Whilst the framework for reviewing texts is largely derived from the work of Karo and Kattel (2016a, 2016b, 2015), a prominent theme emerged around inclusivity - in terms of both approach and outcome - and the extent to which innovation practices contribute towards equitable social and economic development. As a result, the findings and discussion sections explore linkages between inclusivity and innovation discourses, and consider the implications specific organisational and individual roles for achieving this broader outcome.

\section{National public sector innovation context}

Going back to South Africa's recent STI White Paper and its proposal for a stronger government role in innovation, we see an explicit interest in developing a public sector with 'a more innovation-enabling mindset and culture', which includes the use of 'risk procurement' and public official involvement in co-creation activities (DSI 2019, 41). A central feature of the DSI strategy is to embed innovation more deeply in sector departments, especially those involved in high priority 'policy nexuses'. For example, a nexus focused on 'Social' outcomes addresses 'social development and innovation for inclusive development' (DSI 2019, 26). With support from the Department of Planning, Monitoring and Evaluation and National Treasury, the DSI aims 'to facilitate the integration of the STI agenda and plans into government planning' (DSI 2019, 25).

In looking to embed innovation in public entities driving inclusive development activities (and vice versa), DSI-funded scholars have identified a critical need to define the 'capabilities and resources to implement policy instruments effectively and efficiently' (Petersen and Kruss 2019, 366). The push to be more open and inclusive is creating additional complexity for the public entities and officials leading innovation-related work; as well as for the wider community of finance, supply chain and other administrative functions being asked to support these activities.

Looking more broadly, it is important to recognise that proposals for expanding public official involvement in innovation intersect with a wider context and history of South Africa looking to modernise and professionalise the public service. From this perspective, innovation is mainly associated with improving public sector performance, such as by public 
officials adopting an 'entrepreneurial orientation' (Malatjie, Garg, and Rankhumise 2017), using technology, and applying systems thinking (Fraser-Moleketi 2006, 62). The list of actions includes changing red-tape to 'SMART-tape' through, amongst others, simplifying procedures, ensuring procedures address a specific function, and fostering accountability by assigning clear responsibility (CPSI 2004, 38). In addition, for a developmental state such as South Africa, the public sector's relationship to innovation is not confined to improving 'counter-services' but also involves playing a wider role in economic development (Abrahams, Fitzgerald, and Cameron, 1052), pointing to a strong interconnect between internal and external innovation outcomes.

As mentioned above, professionalisation has also now been associated with the idea of an entrepreneurial state, which requires civil servants to be innovative and people-centred. This echoes a more fundamental argument outlined in the Draft Professionalisation Framework that civil servants need to be (re-) anchored by professional values; 'which is about observing and serving people with empathy in accordance with the Constitution, Batho Pele and the Public Service Charter', and also in pursuing continuous development to sharpen their 'know-how' (NSG 2020, 38). The importance of values, as described in the Batho Pele principles, is seen as critical for grounding the civil service and justice system more deeply in South African and African philosophies, such as ubuntu, with its distinctly relational world view (Qobo and Nyathi 2016; Kroeze 2002). In the following sections we see how diverse values, capabilities and legitimacies intersect in three different arenas of innovation, starting with municipalities, provincial governments and national sector departments.

\section{Municipalities, provincial governments and national sector departments}

To encourage innovation in service delivery, the suggestion from local researchers is that public entities can look to support an entrepreneurial orientation amongst government employees; through management support, rewards and autonomy, amongst other actions (Malatjie, Garg, and Rankhumise 2017). Agreement with these recommendations is reflected in some of the measurement frameworks that have been adopted or are being engaged with by municipalities, such as INSEAD's Innovation Readiness Model (IRM) (City of Tshwane 2018) and a Municipal Innovation Maturity Index (MIMI) (Hart, Booyens, and Sinyolo, 2020). MIMI draws on four constructs: Leadership and management support, Organisational enablers of innovation, Individual perceptions, Individual activity. For example, organisational enablers of innovation consider whether innovation is linked to organisational strategy and if there is inter-departmental or external collaboration.

To realise the goals of their innovation strategies, municipalities have typically established research, development and innovation (RDI)-like coordinating functions close to strategy, planning and knowledge management (e.g. City of Tshwane n.d.; City of Cape Town 2017); and/ or in an economic development department or agency, and therefore with more of an external orientation (e.g. eThekwini Municipality 2017; LEDA 2017, 47). From an internal innovation perspective, the legitimacy of these RDI units is derived from their proximity to 
strategy and policy authority. As in the City of Cape Town, their work then involves establishing a partnership with senior management to 'develop and position leadership in the city as advocates of values, role modelling the desired behaviours' (City of Cape Town 2017, 9). The specific practices and tools vary depending on objectives; from implementing quality management systems and lean management, to using design-thinking for building customercentric services, and (co)hosting open innovation platforms for an exchange of knowledge between citizens and employees (City of Cape Town 2020; de Vries 2019; City of Tshwane 2017).

For municipal and provincial governments, there is a growing expectation that they play a more active role in stimulating external innovation in their regions, and this is closely connected to enhancing the delivery of basic services through co-creation with residents. In the STI White Paper, provincial and municipal governments are explicitly linked to increasing the 'spatial footprint of innovation in South Africa' through the expansion of local innovation hubs, incubators and/ or Living Labs as part of broader 'local innovation ecosystems' also consisting of walk-in innovation centres or kiosks (such as at post offices) (DSI 2019, 37).

Ultimately, it is expected that innovation will be more deeply embedded in subnational planning: 'Local and provincial growth and development strategies will include innovation plans. "Innovation hubs" will be expanded to enhance provincial growth and development strategies, and promote provincial technology competencies' (DSI 2019, 37).

Strengthening of regional fora as mechanisms for the expansion of innovation (policy) capabilities in all provinces and more locally has been a consistent priority for DSI over several years. As a 2020 call for proposals by the Council for Scientific and Industrial Research (CSIR) notes, there is a new initiative to (re-)establish a Regional Innovation Support Programme (CSIR 2020, 3). This includes conducting innovation baseline studies of regional innovation systems and ensuring alignment to provincial and local government strategies and policies. Ultimately this will lead to the development of feasibility studies and business plans for science parks or innovation hubs in selected regions, and 'firm commitment' from subnational governments to implement plans if feasible (CSIR 2020, 9). The expectation for subnational governments is that they would leverage physical proximity and cross-sector relationships to establish knowledge sharing spaces and linkages, with a strong emphasis on ensuring 'meaningful participation of previously disadvantaged individuals, including businesses owned by females and people living with disabilities' (CSIR 2020, 5). The role of local fora as more accessible spaces for participation of marginalised groups in innovation activities is clearly critical.

The second, closely related policy intent in the STI White Paper where government features prominently is in supporting 'innovation for social and grassroots innovation'. Here, the public sector can be an enabler by 'strengthening' the use of information and communication technology (ICT) as part of e-government applications and through co-creation and user-led Living Labs. Similar to above, municipalities and provincial governments 'will be 
encouraged to include support for grassroots innovation, and innovation scouting' in their development plans (DSI 2019, 38). Of particular interest is the suggestion that this intent will also require stronger engagement with civil society organisations (CSOs) 'as innovation intermediary between government and grassroots innovators' (DSI 2019, 38). As with the above regional plans, there is an expectation that subnational governments can connect with other sectors to realise (inclusive) innovation outcomes. To enable this, the conclusions from a number of recent inclusion-oriented municipal innovation projects - often aimed at improving the delivery of basic services - are similar in emphasising that national agencies and external actors should not simply push technological innovation in local areas. Instead, innovation should be integrated into local government planning and individual performance management processes. At the same time, sufficient resources and skills need to be allocated for this work, and local politicians and officials are called on to facilitate more participatory and collaborative processes of innovation co-creation and implementation (Biljohn and Lues 2019, 143; Ndabeni, Rogerson, and Booyens 2016; Senyolo et al. 2018; Hart, Booyens, and Sinyolo 2020; Jacobs et al. 2019).

As is evident above, ICT forms a big part of the municipal innovation agenda, from local government broadband infrastructure initiatives (SALGA 2020) to using online platforms and apps to improve participation in policy processes (DSI 2021). The integration of ICT into subnational innovation and knowledge economy strategies (WCPG 2001; GDED 2012; Cartwright et al. 2009) and smart city plans (Backhouse 2015) has become prevalent in provinces and cities across South Africa from the early 2000s. In fact, the national STI White Paper sees ICT as underpinning 'a dynamic, inclusive and prosperous knowledge economy in which seamless information infrastructure and systems will meet the needs of citizens, business and the public sector' (DSI 2019, 17). This view is reinforced by public officials and local research from various sector departments, such as public health (Shipalana, Masango, and Phago 2020) and human settlements (Cooper and Sebake 2018). A key characteristic demanded of ICTs to enable innovation is that they need to be open (DSI 2019; DCDT 2021); as in open access broadband, open data and free and open source software (FOSS). For example, a Limpopo Provincial Government strategy emphasises that FOSS 'supports innovation, local solutions and learning' (Limpopo Connexion 2007).

In the national government sphere, sector departments tend to adopt a more technical approach to innovation through relatively formal research and development (R\&D) relationships with university or industry partners, which are primarily aimed at improving delivery and reducing costs. Often these R\&D relationships are anchored or coordinated by public-funded science councils, many of which report to the relevant sector department (OECD 2007). For example, the Water Research Commission (WRC) aligns its work with the policies of the national Department of Water and Sanitation (DWS) as its 'shareholder department' (WRC 2018, 7), which includes leading specific innovation initiatives (DWS n.d.). Whilst 'hard' R\&D activities tend to be the most visible form of innovation in these sectors, there has also been 'softer' governance innovation for several decades amongst a broader community of government stakeholders looking to address water and sanitation challenges. From relatively early examples, such as the Working for Water program - now 
administered by the Department of Environment, Forestry and Fisheries (DEFF) - a recurring emphasis has been on the capacity to establish 'organizational partnerships and cooperative arrangements' with other departments, as well as with the private and non-governmental sectors (Borins 2006, 14). This is because '[a]n innovation process is rarely if ever contained solely within one unit' (Borins 2006, 10).

The national Department of Health (DoH) works with a wider network of university partners and the Medical Research Council (MRC). The MRC hosts a health innovation initiative supported by the DSI (MRC n.d.). Health is a priority social sector for inclusive innovation, especially because of the critical need to expand access to and improve public health services, as well as the need to address a large disease burden from HIV/AIDS and Tuberculosis in the country. As a result, this sector has seen relatively prolific and visible scientific R\&D around these priority issues (e.g. Columbia University 2020), but also innovation in health systems functioning at national and subnational levels (e.g. MacGregor et al. 2018; Kula and Fryatt 2014; Peter et al. 2018). The rigorous nature of health research and policy development lends itself to high levels of credibility, and a more hierarchical enactment of improvements and changes through a variety of institutional oversight mechanisms. As an example, the South African Health Products Regulatory Authority (SAHPRA) is influential as a gatekeeper for the introduction of new pharmaceuticals, and has itself been implementing a number of managerial innovations to clear a 16,000+ backlog of applications (SAHPRA 2019). For this type of public entity, transparent and efficient operation are priority values in their support of innovation.

Beyond these innovation actors and regulatory mechanisms, there are many important considerations as to how innovation can be enabled in the wider health workforce. Perhaps most significant is the willingness of practitioners to adopt new practices. Managers may use a variety of approaches to 'internalise' and re-package information so that innovations are seen as beneficial to employees' daily activities, instead of being seen to add to their existing burden of work. Given the perceived and actual impact on work routines, gaining buy-in from de-facto leaders and unions also becomes critical (Brooke-Sumner et al. 2019), all of which highlights the importance of managers in health having strong information and political mediation capacities. Much of this is relevant to other sectors such as education (e.g. Mawson 2013), where acknowledging and mediating impact, risks, perceptions and politics around new technologies is critical.

\section{State-owned enterprises}

SOEs traditionally pursue innovation as part of their core function of building infrastructure or providing bulk services, such as water or electricity, via municipalities or directly to citizens. Through innovation, they aim to enhance service quality, increase revenue (including minimising revenue leakage) and reduce costs. In addition to these more internal operational needs, innovation is enrolled as part of a wider SOE narrative captured in the STI White Paper, which aims to leverage their procurement capacity in 'revitalising' technology- 
oriented $R \& D$ towards industrialisation objectives. This includes orienting the sourcing of knowledge and R\&D towards local 'technology accumulation' so that 'SOEs in specific technology spaces will buy from local service providers and institutions rather than from foreign firms' (DSI 2019, 36).

More specifically, a separate section of the STI White Paper on government procurement of innovation notes that ' $[\mathrm{t}]$ he Competitive Supplier Development Programme, championed by SOEs, will also be expanded to include local technologies' (DSI 2019, 34). Technology localisation and industrialisation through SOE procurement is a complex activity which depends on a mix of strategic, financial, legal and technical routines to identify 'specific technology spaces' and facilitate local procurement pathways. 'Major' Schedule 2 SOEs as defined in the Public Finance Management Act (PFMA) No. 1 of 1999, as well as certain other SOEs, do have a degree of financial autonomy in being able to generate their own revenue, but do still have to comply with National Treasury procurement rules (Bronstein and Olivier 2015).

The above statement about the Competitive Supplier Development Programme forms part of a broad policy intent to 'Use public procurement as a vehicle to further innovation' in which it is noted that (probably using Transnet's rail division as an example):

The role of the Public Finance Management Act 1999 in R\&D-related
activities will be made clear (e.g. to differentiate collaboration and
partnerships from procurement-related activities). Technology
conditionality will be built into large procurement contracts (e.g. fleet
procurement for rail) to ensure that South Africa acquires the latest
technologies and that there is technology transfer in the localisation
process (DSI 2019, 34).

This reinforces the envisaged role of SOE (and other) supply chain and procurement officials in managing collaboration and partnerships, not just administering supply chain operation. However, confusion and abuse related to the procurement of innovation has become evident, especially when technically and politically influential consulting and engineering firms are able to capture state resources through opaque 'partnership' arrangements (Plantinga and Adams 2021). The STI White Paper's envisaged clarification of the PFMA (and possibly also the Municipal Finance Management Act (MFMA) No. 56 of 2003) may be overtaken, or enabled by a Public Procurement Bill which aims to achieve wider consolidation, simplification and reform of fragmented legislation. Submissions on the Bill have highlighted an opportunity for placing a stronger focus on 'functionality' as an evaluation criteria along with decentralising some of the procurement authority away from the accounting officer and supply chain team to business units, which would ensure appropriate technical expertise is assigned to bid specification and evaluation - both of which could support a stronger emphasis on innovation. This arrangement may also reduce the likelihood of procurement being captured at a single point in the organisation (PARI 2020). 
National Treasury also approves public-private partnerships (PPPs), which, in the late 1990s, were identified as a key 'alternative service delivery' (ASD) mechanism for improving service delivery. A PPP creates flexibility in how outcomes are achieved and the way activities are financed. Scholars quickly raised concerns that Treasury's PPP guidelines did not fully address contestability and market testing, and that they had a limited focus on technical and financial feasibility, with no mention of environmental, industrial and social implications (Russell and Bvuma 2001). Examples of PPPs and other forms of innovation partnership in the country suggest they can support a more outcomes-based approach to procurement that can benefit the environment and communities. However, the complexity of these processes requires enhanced contracting skills and there continues to be a challenge around public consultation and concern about perceived (and actual) private sector profit maximisation rather than public benefit (WWF 2018; Fombad 2013). So, whilst financial management routines and administrative capacities are a central concern, the issue of social implications and public accountability remains a critical gap.

Certain PPPs offer SOEs an opportunity to generate funds through shared financial rewards. South African SOEs are attracted to the idea of innovation being an alternative source of revenue, through joint ventures and but also through providing services and more passive technology licensing royalties. For Rand Water, new business opportunities have been identified around the production of water treatment chemicals, manufacturing of bricks, and exploiting acid mine drainage water, amongst others. In doing so, they aim to diversify revenue streams and subsidise bulk water tariff increases, or mitigate 'the high risk of nonpayment and high non revenue water by local municipalities' (Rand Water 2019, 154). Similarly for Transnet, R\&D contributes 'to the diversification of Transnet's revenue and business streams, with the intention of expanding from the commodity product portfolio to higher value-adding products and services' (Transnet 2019, 67), with a key objective to export products and services to other African countries as an original equipment manufacturer (Transnet 2019, 57).

Many SOEs now have some form of RDI function or unit - typically situated near a central strategy or engineering division - which provides administrative, monitoring, coordination and/ or implementation support for RDI activity. Rand Water's innovation-oriented strategy includes establishing a 'fully-functional Innovation Hub' (Rand Water 2019, 44). Internal $\mathrm{R} \& \mathrm{D}$ entities and collaborations with universities, research councils and industry research partners have existed for decades, partly because of SOE funding for research but also because large numbers of graduates are employed in these entities. The addition of innovation as a broader, organisational culture issue is relatively new. As a result, RDI functions are often expected to sustain traditional R\&D relationships aimed at scientific innovation (supporting both operational and business development goals), as well as facilitating broad awareness and day-to-day incremental innovation across the organisation (Rand Water 2019, 44). This support for incremental innovation tends to overlap with staff performance management processes. As a result, HR and internal communications have become more influential in this space, but the legitimacy of RDI support in SOEs is still closely tied to engineering qualifications and experience. 
In responding to the SOE need for technical skills generally, and the significant skills gap in the country, the STI White Paper outlines plans to continue the racial transformation of engineering human capital by supporting stronger links between SOEs and higher education and vocational training programmes (DSI 2019, 36). SOEs have relatively well-developed training and graduate recruitment pipelines, and this model fits well with standardised SOE HR routines.

However, these graduate recruitment processes have also overlapped with more innovationoriented entrepreneur and 'supplier development' initiatives. Transnet describes the a programme to support 'the rise of young black entrepreneurs through the various developmental levels - from high-school innovation programmes to business case development and business incubation to our Black Industrialists Programme and our regional and global exporting and trade programmes' (Transnet 2020, 32). Clearly these initiatives have strong inclusion goals, but they are not without complexity and challenges.

First is the expectation that new or pre-graduates will 'provide solutions' to operational challenges (eThekwini Municipality 2018), or 'turn ideas into viable technology solutions to speed up service delivery' (Sidler 2018). Second, is the somewhat unclear approach to legal issues, such as indicating that 'foreground' intellectual property (IP) will be managed in accordance with the Intellectual Property Rights from Publicly Financed Research and Development Act No. 51 of 2008 (IPR Act); legislation and terms most young innovators will be unfamiliar with (SITA 2019). This language creates expectations for innovators and SOEs that outputs of these engagements will be implemented, which seems unlikely in the short term and rarely happens over the long term, along with confusion about ownership of IP, leading to cynicism about future participation. Normal SOE legal, HR and financial routines seek efficiency using standardised outputs, which are not always appropriate for these types of engagements. Careful customisation is therefore needed to facilitate meaningful engagement with emerging (and more established) innovators.

\section{Public sector innovation intermediaries}

As a key government innovation intermediary, the Centre for Public Service Innovation (CPSI) is a component of the Department of Public Service and Administration (DPSA), which is itself responsible for developing a 'professional, productive and responsive public service and administration' (DPSA n.d.). Within this broader departmental mandate, the CPSI's role has been re-asserted 'to inculcate and drive the culture and practice of innovation in the public sector as a critical transformative catalyst and enabler for improved service delivery and performance' (CPSI 2020, 2). By being relatively deeply embedded in a government department, and with a clear intra-governmental mandate, the CPSI's routines are quite closely tied to its parent department and the rules of the public sector. Central to CPSI's role is 'replicating' innovations identified through its knowledge platforms and annual awards ceremony. This is done by promoting 'cross-sector and inter-sphere 
collaboration and co-innovation amongst government institutions' (CPSI 2020, 2). However, the new strategic plan emphasises that, given its limited capacity and the multi-phase nature of innovation adoption, the CPSI only anticipates replicating two projects - probably over the current financial year (CPSI 2020,11). In addition to these capacity constraints, a key weakness and risk highlighted a number of times is the 'strict regulatory restrictions related to its corporate form' (CPSI 2020, 11) and an associated 'restrictive fiscal environment' (CPSI 2020, 15), which limits its ability to facilitate contracting with innovators. The need to be more flexible has led to questions about its 'repositioning' under other departments that are seen to be more receptive to innovation, such as the DSI (PMG 2020).

Nonetheless, the CPSI seeks to work through partnerships, such as plans to collaborate with the National School of Government (NSG) to provide training on public sector innovation topics (PMG 2020). In recent years, the NSG has been offering a course on 'Leading innovation in the public service' (NSG 2018). Perhaps more significantly, in the Draft Professionalisation Framework the NSG outlines proposals to integrate innovation into government's Planning and Performance Management to 'create the space for innovation and risk taking' (NSG 2020, 84); and to refresh an existing 'Revolving Door Policy' which allows for movement of senior management between private sector, academia and the public sector as a way to introduce new ideas (NSG 2020, 90). Recent cabinet support for the NSG leading professionalisation work (South African Government 2020) and participation of the President in an innovation-oriented training hosted by the NSG (The Presidency 2021) suggests a renewed legitimacy for professionalisation and the role of innovation.

Aside from the NSG and CPSI there are a number of other public and quasi-public national and subnational entities shaping the direction of public sector innovation. Two of these are the South African Cities Network (SACN) and the South African Local Government Association (SALGA). SALGA's innovation support ranges from more technology-oriented guidance, such as on broadband as a ' $5^{\text {th }}$ Utility' and Smart Cities framework development, to broader performance improvement and the modernisation and professionalisation of local government via training and support on systems and processes (SALGA 2020). A key part of SALGA's function is engaging with the various spheres of government on the precarious financial state of most municipalities, on issues such as 'unfunded mandates' and debt to SOEs, and to explore innovative ways of addressing these challenges. As associations, largely funded by and representing the interests of local governments, they are accountable to their members (SALGA 2020, 52), requiring a stronger advocacy-like political and policy capacity.

For all of these intermediary entities, again, leveraging ICT has become a key part of how they see themselves relating to innovation. E-learning as an innovation training option has gained prominence, especially in a post-COVID-19 era (PMG 2020). The Innovation Hub (TIH), another provincial government innovation intermediary, launched an OpenIX programme in 2013 which, over 6 years, ran over 50 open innovation 'challenges' to connect innovators with social and service delivery needs posted by public sector entities. It also facilitated partner (co-) financing of several pilot projects implemented by entrepreneurs in 
government departments (de Vries 2019; GGDA 2019: 89). For OpenIX, in the initial launch years, the majority of resources were allocated to enrolling new challenge owners and, with a team of people, searching and contacting innovators directly to build trust in the process and source high quality proposals. In 2018, resources were re-directed towards building a new online platform (TIH 2018), with a more managed user experience that potentially supports more passive trust-building, whilst leveraging TIH's now quite wide social media and email audience for viral outreach.

\section{Discussion}

Whilst the OECD (2007) noted the increased institutional variety in South Africa's innovation policy sub-system post-apartheid, there is - for inclusive development outcomes especially - a potentially more significant diversification of innovation management taking place inside government sector departments, SOEs and municipalities. This can have benefits for inclusion but can also create confusion about priorities and new tensions, such as when innovation procurement does not follow supply chain rules. At the same time, there is an opportunity in this variety, to more carefully identify, recognise and amplify complementary capacities that can enable the sourcing and scaling of ideas as they are tested and developed internally and in the market (van der Wal 2017).

In Table 2, the framework of routines and capacities outlined by Karo and Kattel (2016a; 2016 ; 2015) is used to extract and map out the different organisations and suborganisational units or individuals described in the case studies above. Only selected routines and capacities are noted as a preliminary insight into the broad characteristics of innovation action.

\section{[Table 2 near here]}

Starting with the first row of Table 2, municipalities have been an increasingly popular focus for innovation policymakers and scholars globally and now in South Africa. The first reason is because of their physical proximity to residents and citizens, and the importance of strong local connections to innovation outcomes (Cooke 2008). The other reason is their central role as the 'face of government' and responsibility for delivering basic services, for which there is overwhelming demand for improvements in quality and expansion to underserved populations. It is mainly because of the latter pressure that municipalities have established RDI units, which are oriented to enhancing organisational performance. The same applies to sector departments and SOEs. As described in the case study, the RDI units' main routine relates to coordination: communicating and engaging with service delivery divisions to enrol senior management as champions of innovation, then supporting them with relevant tools and resources to embed innovation practices or outcomes within standardised work processes and personnel management (such as performance scorecards).

A key mechanism to enable inclusion-oriented service delivery improvement is through more meaningful community feedback, participation and 'customer' relations, in both local 
government planning and delivery of services to residents, and this can be supported by proposed local innovation fora. In the case of SOEs - which tend to be wholesale or bulk service providers - more attention could be placed on how they relate to municipalities as their immediate customers and as potential co-innovators in how services are delivered to residents. This requirement again speaks to collaborating capacities in the coordinating routine, but with more of an external perspective.

Another high priority area that spans internal innovation needs and external engagement is procurement: the primary concern for municipal, sector department of SOE business units and divisions is improving operations through better value for money from contracted service providers. In procuring products and services, elevating functionality as an evaluation criterion (rather than using minimum levels of functionality) and allowing business units more freedom to appoint technical skills to bid specification and evaluation committees are two proposed responses. At the same time, accounting officers and supply chain management (SCM) officials may be pursuing increased diversity of suppliers, through procurement evaluation criteria but also by supporting supplier development programmes. These initiatives require a deep knowledge of value chains and an ability to build partnerships with specialised incubators.

Innovation leaders, along with business unit and technical partners, can better recognise and support the importance of procurement values (e.g. transparency and accountability), by offering to co-design compliant processes and policies with supply chain officials. This can include making more information on innovation procurement or PPP interactions available online and designing ways to manage or delimit service provider confidentiality. Updated National Treasury regulations could assist with defining confidentiality limits and enable shared understanding between these internal actors. By recognising different capacities (and priorities or values) and identifying unit-relevant policy and process adjustments, the pathway for developing and scaling up innovations - from basic R\&D, through business unit testing and piloting and scaling - can be more sustainable (van der Wal 2017). As a byproduct from supporting supply chain priorities of fairness and transparency, the potential for clean processes and audits is increased, which reinforces the organisation's legitimacy and trust amongst internal and external stakeholders.

With growing interest in PPPs as a mechanism for more collaborative and innovative service design, the importance of transparency and public participation become even more critical. The case study highlighted gaps in PPP management related to social implications, contestability and public consultation and accountability. In this respect, public entities require specific political and policy capacity for stakeholder consultation, establishing political commitment, transparent procurement, ensuring appropriate risk transfer and contract monitoring (Fombad 2013; WWF 2018; Russell and Bvuma 2001; Forrer et al. 2010).

The same applies to more externally-oriented initiatives, such as local economic development (LED) programmes. LED departments in the municipalities are able to address infrastructure, 
zoning and licensing issues which can be leveraged for partnerships that serve the interests of certain areas and communities. SOEs manage access to large amounts of land and infrastructure and are therefore in a similar position to LED entities as broader enablers of economic activity, beyond the procurement role. For both LED and SOE actors, being able to identify suitable opportunities for leveraging these capabilities and resources to support innovation requires openness to information about market trends, as well as strong commercial capacities for negotiating partner agreements - particularly if looking to involve local enterprises. In an era of growing city economies and multi-national SOEs, this broader facilitation role needs to span local and global networks, whilst recognising the importance of adhering to principles related to public participation and accountability emphasised earlier.

\section{Conclusion}

For the public sector to achieve its innovation goals and, ultimately, more inclusive service delivery, there is a need for deeper recognition of the diverse legitimacies, capacities and routines supporting inclusive development outcomes. Instead of seeking wholesale change of mindset and de-bureaucratisation of government (Chipkin and Lipietz 2012, 23), this paper has sought to identify specific roles for which specific capabilities can be developed towards sustainable innovation relationships and outcomes.

By conducting a mainly organisational-level analysis, this paper does not comment on the broader dynamics and resource allocations which have been the subject of previous research related to South Africa's system of innovation (e.g. OECD 2007). It has also not explored the underlying motivations which may inspire public officials to support innovation. A more holistic view is potentially critical. As the Observatory of Public Sector Innovation argues in its analysis of Brazil's public sector innovation environment, lower-level, ad-hoc innovation needs to be supported by more systemic actions and clarification about 'why it is needed, why it matters to the Public Service of Brazil (and Brazil more broadly) and what is expected of public servants and external stakeholders' (OECD 2019b).

For South Africa a question then arises as to why public sector innovation is needed and why it matters. Specifically, as mentioned in the paper, are there more locally anchored ideals and principles such as ubuntu and Batho Pele which can serve as an overarching 'mandate' (Drechsler and Karo 2017) or motivation for public servants to support innovation? Drawing on its relational worldview, international scholars have appropriated ubuntu in calling for a more holistic or systemic perspective on innovation (Laszlo 2018). Clearly there would be broad relevance to innovation, and inclusive development especially. However, through a more nuanced perspective we can be sensitive to how ubuntu and similar concepts are assimilated to varying degrees in our public service and innovation culture, such as through Batho Pele principles (Qobo and Nyathi 2016; Kroes 2002), as well as the potential for ubuntu to inform an African ethics on emerging 'public interest' technologies (Mhlambi 2020). At the same time we should be aware of the risk that these concepts become commercialised as part of technocratic, elite-driven innovation processes which can further 
exclude the public officials and marginalised groups that are most heavily impacted by innovation-enabled changes (Matolino and Kwindingwi 2013; McDonald 2010).

\section{References}

Abrahams, L., P. Fitzgerald, and R. Cameron. 2009. “A single public service for South Africa: Process and prospects.” Journal of Public Administration 44 (4/1):1046-1066.

Avgerou, C., and C. Bonina. 2020. "Ideologies implicated in IT innovation in government: A critical discourse analysis of Mexico's international trade administration." Information Systems Journal 30 (1):70-95.

Backhouse, J. 2015. "Smart city agendas of African cities." In Proceedings of 1st African Conference on Information Systems and Technology (ACIST), Accra, Ghana, July 7-8.

Bason, C. (2018). Leading Public Sector Innovation 2E: Co-creating for a Better Society. Bristol: Policy Press.

Biljohn, M. I., and L. Lues. 2019. "Social innovation and service delivery in Belgium and South Africa." Transforming Government: People, Process and Policy 13 (2):143-158.

Booyens, I., K. Nyezi, A. Bolosha, S. Sinyolo, and P. Jacobs. 2019. Municipal Innovation Maturity Index: towards a digital platform: refining and aligning MIMI. https://repository.hsrc.ac.za/bitstream/handle/20.500.11910/15295/11348.pdf?sequence=1\&is Allowed $=\mathrm{y}$

Borins, S. 2006. The challenge of innovating in government. IBM Center for the Business of Government.

Bronstein, V., and M. Olivier. 2015. An evaluation of the regulatory framework governing state owned enterprises (SOEs) in the republic of South Africa: Technical Report. Pretoria: The Presidency, Republic of South Africa.

Brooke-Sumner, C., P. Petersen-Williams, J. Kruger, H. Mahomed, and B. Myers. 2019. "'Doing more with less': a qualitative investigation of perceptions of South African health service managers on implementation of health innovations." Health policy and planning 34 (2):132-140.

Cartwritght, A., M. Gastrow, J. Lorentzen, and S. Robinson. 2009. Limpopo Integrated Innovation Strategy (LIIS). Human Sciences Research Council, Econologic, Economic Rise.

Chataway, J., C. Daniels, L. Kanger, M. Ramirez, J. Schot, and E. Steinmueller. 2017. "Developing and enacting transformative innovation policy: a comparative study." Paper 
presented at the 8th International Sustainability Transitions Conference, Gothenberg, Sweden, June 18-21.

Chipkin, I., and B. Lipietz. 2012. "Transforming South Africa's Racial Bureaucracy New Public Management and public sector reform in contemporary South Africa." Public Affairs Research Institute (PARI) Long Essays, Number 1.

City of Cape Town. 2017. Organisational Development and Transformation Plan (ODTP). Cape Town: City of Cape Town. https://resource.capetown.gov.za/documentcentre/Documents/City\%20strategies, \%20plans\% 20and\%20frameworks/Organisational\%20Development\%20and\%20Transformation\%20Plan $\% 20($ ODTP).pdf

City of Cape Town. 2020. "Talent Rich Cape Town a Leader in Innovation." City of Cape Town - News. October 30. https://destination.investcapetown.com/talent-rich-cape-town/

City of Tshwane. n.d. City Strategy and Organisational Performance. Pretoria: City of Tshwane. http://www.tshwane.gov.za/sites/Departments/CSOP/Pages/default.aspx

City of Tshwane. 2018. Annexure A - Council Meeting: 30 August 2018. Pretoria: City of Tshwane https://www.tshwane.gov.za/sites/Council/Lists/Council\%20Calendar/Attachments/58/04.\%2 0ANNEXURE\%20A\%20MAYCO\%2017\%207\%202018\%20Council\%2030\%2008\%20201 8.pdf

Columbia University. 2020. Abdool Karims Receive Prestigious Global Health Award. April 27. https://www.publichealth.columbia.edu/public-health-now/news/abdool-karims-receiveprestigious-global-health-award

Cooke, P. 2008. "Regional innovation systems: origin of the species." International Journal of Technological Learning, Innovation and Development 1 (3): 393-409.

Cooper, A. K., and N. Sebake. 2018. "Neighbourhood 4.0: A response to urban futures." Paper presented at Out-Of-The Box 2018 Conference, Pretoria, South Africa, October 24-25.

CPSI (Centre for Public Service Innovation). 2004. Future Watch: From Red Tape to Smart Tape: Easing the Administrative Burden of Public Service Delivery. Pretoria: Centre for Public Service Innovation, Republic of South Africa.

CPSI (Centre for Public Service Innovation). 2020. Centre for Public Service Innovation Strategic Plan for 2020 - 2025. Pretoria: Centre for Public Service Innovation, Republic of South Africa. 
CSIR (Council for Scientific and Industrial Research). 2020. Call for proposals (CFP) Regional Innovation Support Programme (RISP). Ref No. TLIU/RIS04/2020. Pretoria: Council for Scientific and Industrial Research, Republic of South Africa.

Daniels, C., J. Schot, J. Chataway, M. Ramirez, E. Steinmueller, and L. Kanger. 2020. "Transformative Innovation Policy: Insights from Colombia, Finland, Norway, South Africa, and Sweden." In Innovation policy: global debates and local experiences, edited by M. B. G. Cele, T. M. Luescher, and A. Willson Fadiji. Cape Town: HSRC Press.

DCDT (Department of Communications and Digital Technologies). 2021. Draft National Policy on Data and Cloud. Pretoria: Department of Communications and Digital Technologies, Republic of South Africa. https://www.gov.za/sites/default/files/gcis_document/202104/44389gon206.pdf

de Vries, H., V. Bekkers, and L. Tummers. 2016. "Innovation in the public sector: A systematic review and future research agenda." Public administration 94 (1):146-166.

de Vries, A. 2019. "South African OpenIX programme - creating linkages between government, industry and research." Presented at IASP Africa Division Workshop, The Innovation Hub, Pretoria, May 23-24. http://www.iaspafrica2019workshop.co.za/programme/

DPSA (Department of Public Service and Administration). n.d.. About the DPSA. Pretoria: Department of Public Service and Administration, Republic of South Africa http://www.dpsa.gov.za/about.php

Drechsler, W., and E. Karo. 2017. "Confucian Public Administration and Innovation Policy: A Conceptual Perspective - Mencius, Max Weber and the Mandate of Heaven”. Paper presented at the 3rd International Conference on Public Policy (ICPP3), Singapore, June 2830.

DSI (Department of Science and Innovation). 2019. White Paper on Science, Technology and Innovation. Pretoria: Department of Science and Innovation, Republic of South Africa.

DSI (Department of Science and Innovation). 2021. Viability and Validation of Innovations for Service Delivery Programme (VVISDP) - Municipal Briefing Workshop. Pretoria: Department of Science and Innovation, Republic of South Africa.

Dutta, S., B. Lanvin, T. R. Singh, A. Green, V. Berthelon, and G. B. S. Bingra. 2009. Are you innovation ready? Plotting your journey on the Innovation Readiness Model. INSEAD and Logica. https://innovationmanagement.se/images/stories/file/INSEAD_report.pdf

DWS (Department of Water and Sanitation). n.d.. Research and Innovation - Sustainable Development Goal 6. Pretoria: Department of Water and Sanitation, Republic of South Africa. https://www.dws.gov.za/Projects/sdg/Research\%20Innovation.aspx 
eThekwini Municipality. 2017. City to Launch Innovate Durban Legal Entity. Durban: eThekwini Municipality, Republic of South Africa.

http://www.durban.gov.za/Resource_Centre/Press_Releases/Pages/City-TO-LaunchInnovate--Durban-Legal-Entity.aspx

eThekwini Municipality. 2018. Maritime Sector to Take Centre Stage on the 2018 Youth Innovation Challenge. Durban: eThekwini Municipality, Republic of South Africa http://www.durban.gov.za/Resource_Centre/Press_Releases/Pages/Maritime-Sector-to-TakeCentre-Stage-on-the-2018-Youth-Innovation-Challenge.aspx

Fairclough, N. 2005. "Peripheral vision: Discourse analysis in organization studies: The case for critical realism." Organization studies 26 (6):915-939.

Fombad, M. C. 2013. "Accountability challenges in public-private partnerships from a South African perspective.” African Journal of Business Ethics 7 (1):11-25.

Forrer, J., J. E. Kee, K. E. Newcomer, and E. Boyer. 2010. "Public-private partnerships and the public accountability question." Public administration review 70 (3):475-484.

Foster, C., and R. Heeks. 2015. "Policies to support inclusive innovation." Development Informatics Working Paper, 61. Centre for Development Informatics, Institute for Development Policy and Management, SEED, University of Manchester.

Fraser-Moleketi, G. J. 2006. Public service reform in South Africa: An overview of selected case studies from 1994-2004. Doctoral dissertation, University of Pretoria.

GDED (Gauteng Department of Economic Development). 2012. Gauteng Innovation and Knowledge Economy Strategy. Johannesburg: Gauteng Department of Economic Development, Republic of South Africa.

GGDA (Gauteng Growth and Development Agency). 2019. Annual Report 2018/19. Johannesburg: Gauteng Growth and Development Agency, Republic of South Africa.

Hart, T. G., I. Booyens, and S. Sinyolo. 2020. "Innovation for development in South Africa: experiences with basic service technologies in distressed municipalities." Forum for Development Studies 47 (1):23-47.

Hood, C. 1991. “A public management for all seasons?” Public administration 69 (1): 3-19.

Jacobs, P.T., A. Habiyaremye, B. Fakudze, K. Ramoroka, and S. Jonas. 2019. "Producing knowledge to raise rural living standards: how universities connect with resource-poor municipalities in South Africa." The European Journal of Development Research 31 (4):881901. 
Karo, E., and R. Kattel. 2015. "Economic development and evolving state capacities in Central and Eastern Europe: can "smart specialization" make a difference?" Journal of Economic Policy Reform 18 (2):172-187.

Karo, E., and R. Kattel. 2016a. "How to organize for innovation: entrepreneurial state and organizational variety." Working Papers in Technology Governance and Economic Dynamics No. 66. The Other Canon Foundation, Tallinn University of Technology.

Karo, E., and R. Kattel. 2016b. "Innovation and the state: towards an evolutionary theory of policy capacity." Working Papers in Technology Governance and Economic Dynamics No. 72. The Other Canon Foundation, Tallinn University of Technology.

Kroeze, I. J. 2002. "Doing things with values II: the case of ubuntu." Stellenbosch L. Rev., 13: 252-264.

Kula, N., and R. J. Fryatt. 2014. "Public-private interactions on health in South Africa: opportunities for scaling up." Health policy and planning 29 (5):560-569.

Laszlo, A. 2018. "Leadership and systemic innovation: socio-technical systems, ecological systems, and evolutionary systems design." International Review of Sociology 28 (3):380391.

LEDA (Limpopo Economic Development Agency). 2017. Annual Report 2016/17. Limpopo Economic Development Agency: Lebowakgomo, Republic of South Africa.

Lee, P. 2015. "Before the Backlash, Let's Redefine User-Centered Design.” Stanford Social Innovation Review, August 26.

https://ssir.org/articles/entry/before_the_backlash_lets_redefine_user_centered_design Limpopo Connexion. 2019. Limpopo FOSS Strategy.

https://limpopoconnexion.co.za/limpopo-foss-strategy/

MacGregor, H., A. McKenzie, T. Jacobs, and A. Ullauri. 2018. "Scaling up ART adherence clubs in the public sector health system in the Western Cape, South Africa: a study of the institutionalisation of a pilot innovation." Globalization and health 14 (1): 40.

Malatjie, I., A. Garg, and E. Rankhumise. 2017. "Corporate entrepreneurship in the public sector: a South African perspective." Paper presented at the International Conference on Public Administration and Development Alternatives (IPADA), Gaborone, Botswana, July 26-28.

Margetts, H. 2011. “The Internet and Transparency.” The Political Quarterly 82 (4):518-521. 
Matolino, B., and W. Kwindingwi. 2013. "The end of ubuntu." South African Journal of Philosophy 32 (2):197-205.

Mawson, N. 2013. "Education still pondering biometrics." ITWeb. April 25. https://www.itweb.co.za/content/8RgeVDqPegQvKJN3

McDonald, D. A. 2010. "Ubuntu bashing: the marketisation of 'African values' in South Africa." Review of African Political Economy 37 (124):139-152.

Mhlambi, S. 2020. "From Rationality to Relationality: Ubuntu as an Ethical \& Human Rights Framework for Artificial Intelligence Governance." Carr Center Discussion Paper. Carr Centre for Human Rights Policy, Harvard Kennedy School. 2020 - 009.

Moodysson, J., M. Trippl, and E. Zukauskaite. 2017. "Policy learning and smart specialization: balancing policy change and continuity for new regional industrial paths." Science and Public Policy 44 (3):382-391.

Mosiea, T. H., T. N. Ngoveni, N. P. Lukhele, S. L. Myeni, and A. E. Okem. 2018. "Innovations for improving service delivery: A case study of the innovation partnership for rural development programme." Paper presented at the Out-Of-The Box 2018 Conference, Pretoria, South Africa, October 24-25.

Mulgan, G., and D. Albury. 2003. Innovation in the Public Sector. Strategy Unit, Cabinet Office, London, United Kingdom.

MRC (Medical Research Council). n.d. Strategic Health Innovation Partnerships (SHIP). Cape Town: Medical Research Council, Republic of South Africa. https://www.samrc.ac.za/innovation/strategic-health-innovation-partnerships

Nabatchi, T. 2018. "Public values frames in administration and governance." Perspectives on Public Management and Governance 1 (1):59-72.

Ndabeni, L. L., C. M. Rogerson, and I. Booyens. 2016. "Innovation and local economic development policy in the global South: New South African perspectives." Local Economy (31) 1-2: 299-311.

Ngcobo, N. 2021. "Corruption destroyed state's ability to get things done, says Ramaphosa." SABC News. March 25. https://www.sabcnews.com/sabcnews/corruption-destroyed-statesability-to-get-things-done-says-ramaphosa/

Ndabeni, L. L., Rogerson, C. M., and Booyens, I. (2016). Innovation and local economic development policy in the global South: New South African perspectives. Local Economy, 31(1-2), 299-311. 
NSG (National School of Government). 2020. A National Implementation Framework towards the Professionalisation of the Public Service (Draft). Government Gazette No. 44031. December 24. 37-98. Pretoria: National School of Government, Republic of South Africa

NSG (National School of Government). 2018. Course Directory. Pretoria: National School of Government, Republic of South Africa. https://www.thensg.gov.za/wpcontent/uploads/2018/07/NSG_Course_Directory-D2-FINAL-05_07-proof.pdf

OECD (Organisation for Economic Co-operation and Development). 2007. OECD Reviews of Innovation Policy: South Africa 2007. Paris, OECD.

OECD (Organisation for Economic Co-operation and Development). 2017. Making Innovation Benefit All: Policies for Inclusive Growth. Paris, OECD.

OECD (Organisation for Economic Co-operation and Development). 2019a. Embracing Innovation in Government: Global Trends 2019. Paris, OECD.

OECD (Organisation for Economic Co-operation and Development). 2019b. The Innovation System of the Public Service of Brazil: An Exploration of its Past, Present and Future Journey. Paris: OECD.

Osborne, S. P., Z. Radnor, and G. Nasi. 2013. "A new theory for public service management? Toward a (public) service-dominant approach.” The American Review of Public Administration 43 (2):135-158.

PARI (Public Affairs Research Institute). 2020. Draft Public Procurement Bill [B-2020]: Submission of Public Comments. Johannesburg: PARI. https://pari.org.za/submission-to-thedraft-public-procurement-bill/

Peter, J., P. Benjamin, A. E. LeFevre, P. Barron, and Y. Pillay. 2018. "Taking digital health innovation to scale in South Africa: ten lessons from MomConnect." BMJ Global Health 3 (2): $1-3$.

Pedersen, A. R., and M. B. Johansen. 2012. "Strategic and everyday innovative narratives: Translating ideas into everyday life in organizations." The Innovation Journal, 17 (1):2-18.

Petersen, I. H., and G. Kruss. 2019. "Promoting alignment between innovation policy and inclusive development in South Africa." Development Southern Africa 36 (3): 351-375.

Plantinga, P., and R. Adams. 2020. "Rethinking open government as innovation for inclusive development: Open access, data and ICT in South Africa." African Journal of Science, Technology, Innovation and Development 13 (3):315-323. 
Plantinga, P., and R. Adams. 2021. "Can open government support innovation for inclusive development? A case study of public innovation policy and management in South Africa." International Journal of Technological Learning, Innovation and Development 13 (2):142167.

PMG (Parliamentary Monitoring Group). 2020. DPSA \& CPSI 2020/21 Annual Performance Plans; with Deputy Minister, National Assembly Committee: Public Service and Administration, Performance Monitoring and Evaluation, Cape Town: National Assembly, Republic of South Africa. https://pmg.org.za/committee-meeting/30212/

Qobo, M., and N. Nyathi. 2016. "Ubuntu, public policy ethics and tensions in South Africa's foreign policy." South African journal of international affairs 23 (4):421-436.

Ramalingam, B. and J. Prabhu. 2020. "Innovation, development and COVID-19: Challenges, opportunities and ways forward." OECD Policy Responses to Coronavirus (COVID-19). December 1. http://www.oecd.org/coronavirus/policy-responses/innovation-developmentand-covid-19-challenges-opportunities-and-ways-forward-0c976158/

Rand Water. 2019. 2019 Integrated Annual Report. Johannesburg: Rand Water, Republic of South Africa.

Russell, E. W., and D. G. Bvuma. 2001. "Alternative service delivery and public service transformation in South Africa." International Journal of Public Sector Management 14 (3):241-264.

SAHPRA (South African Health Products Regulatory Authority). 2019. Backlog clearance project. Pretoria: South African Health Products Regulatory Authority, Republic of South Africa. https://www.sahpra.org.za/backlog/

SALGA (South African Local Government Association). 2020. Revised Strategic Plan 20172022 Annual Performance Plan 2020-2021. Presentation to the Portfolio Committee on Cooperative Governance and Traditional Affairs (CoGTA), May 12.

Senyolo, M. P., T. B. Long, V. Blok, and O. Omta. 2018. "How the characteristics of innovations impact their adoption: An exploration of climate-smart agricultural innovations in South Africa." Journal of Cleaner Production 172:3825-3840.

Shipalana, M. L., S. R. Masango, and K. G. Phago. 2020. "What considerations exist for innovative public health management in the age of the Fourth Industrial Revolution?" African Journal of Science, Technology, Innovation and Development, 1-9.

Sidler, V. 2018. "SITA launches \#NDP2030 hackathon.” MyBroadband. https://mybroadband.co.za/news/industrynews/265749-sita-launches-ndp2030hackathon.html 
SITA (State Information Technology Agency). 2019. NDP2030 Hackathon Participation Terms and Conditions. Pretoria: State Information Technology Agency, Republic of South Africa http://www.ndp2030hackathon.gov.za/sites/default/files/NDP2030_Hackathon_Terms_and_ Conditions.pdf

Sørensen, E., and J. Torfing. 2012. "Introduction: Collaborative innovation in the public sector." The Innovation Journal 17 (1): 1-14.

South African Government. 2020. Statement on virtual Cabinet Meeting of 18 November 2020. Pretoria: Republic of South Africa. https://www.gov.za/speeches/statement-virtualcabinet-meeting-18-november-2020-19-nov-2020-0000

The Presidency. 2021. President to participate in the National School of Government Master Class presented by Prof Mariana Mazzucato. Pretoria: The Presidency, Republic of South Africa. http://www.thepresidency.gov.za/press-statements/president-participate-nationalschool-government-master-class-presented-prof-mariana-mazzucato

Thomas, J. C. 2013. "Citizen, customer, partner: Rethinking the place of the public in public management." Public Administration Review 73 (6):786-796.

TIH (The Innovation Hub). 2018. Awarded Bid for Creation of New Open Innovation Exchange (OpenIX) (TIH/2018/01). Pretoria: The Innovation Hub Management Company, Republic of South Africa. https://www.theinnovationhub.com/about-us/tenders/tendersawarded

Transnet. (2019). Integrated Report 2019. Johannesburg: Transnet, Republic of South Africa.

Transnet. (2020). Integrated Report 2020. Johannesburg: Transnet, Republic of South Africa.

van der Wal, Z. 2017. The 21st century public manager. London: Palgrave.

Vivona, R., Demircioglu, M. A., and Raghavan, A. 2021. "Innovation and Innovativeness for the Public Servant of the Future: What, Why, How, Where, and When" In The Palgrave Handbook of the Public Servant, edited by H. Sullivan, H. Dickinson, and H. Henderson, 1643-1664. London: Palgrave Macmillan.

Voegtlin, C., and A. G. Scherer. 2017. "Responsible innovation and the innovation of responsibility: Governing sustainable development in a globalized world." Journal of business ethics 143 (2): 227-243. 
WCPG (Western Cape Provincial Government). 2001. Preparing the Western Cape for the Knowledge Economy of the 21st Century - White Paper. Cape Town: Western Cape Provincial Government, Republic of South Africa.

WRC (Water Research Commission). 2018. WRC Corporate Plan 2018/19 - 2022/23. Pretoria: Water Research Commission, Republic of South Africa.

WWF (World Wildlife Fund). 2018. Moving Towards Sustainable Performance-Based Procurement in the Western Cape. A guidebook for supply chain managers. WWF South Africa.

Table 1: Taxonomy of organisations and routines (adapted and reduced from Karo and Kattel 2016a, 2016b, 2015)

\begin{tabular}{|c|c|c|c|c|c|}
\hline $\begin{array}{l}\text { Organisation } \\
\text { type }\end{array}$ & Entrepreneurial & Machine & Diversified & Professional & Innovative \\
\hline $\begin{array}{l}\text { Organisationa } \\
\text { I routines }\end{array}$ & $\begin{array}{l}\text { Simple; informal; } \\
\text { flexible; little } \\
\text { staff or middle- } \\
\text { level hierarchy }\end{array}$ & $\begin{array}{l}\text { Centralized } \\
\text { bureaucracy; } \\
\text { formalized; } \\
\text { specialized } \\
\text { work, division } \\
\text { of labour }\end{array}$ & $\begin{array}{l}\text { 'Divisions' } \\
\text { loosely } \\
\text { coupled } \\
\text { together under } \\
\text { headquarter }\end{array}$ & $\begin{array}{l}\text { Bureaucratic, } \\
\text { decentralized; } \\
\text { pigeonholes' } \\
\text { for } \\
\text { professional } \\
\text { autonomy }\end{array}$ & $\begin{array}{l}\text { Fluid, organic, } \\
\text { selectively } \\
\text { decentralized } \\
\text { 'adhocracy' } \\
\text { (multidisciplinar } \\
\text { y task forces) }\end{array}$ \\
\hline $\begin{array}{l}\text { Strategic } \\
\text { management } \\
\text { routines }\end{array}$ & $\begin{array}{l}\text { Visionary, } \\
\text { flexible, } \\
\text { leadership based }\end{array}$ & $\begin{array}{l}\text { Planning that } \\
\text { is strategic } \\
\text { programming }\end{array}$ & $\begin{array}{l}\text { 'Corporate' } \\
\text { portfolio } \\
\text { strategy and } \\
\text { divisions with } \\
\text { individual } \\
\text { strategies }\end{array}$ & $\begin{array}{l}\text { Stable and also } \\
\text { many } \\
\text { fragmented } \\
\text { strategies by } \\
\text { professional } \\
\text { judgment and } \\
\text { collective } \\
\text { choice }\end{array}$ & $\begin{array}{l}\text { Largely } \\
\text { emergent, } \\
\text { evolving through } \\
\text { a variety of } \\
\text { bottom-up } \\
\text { processes }\end{array}$ \\
\hline $\begin{array}{l}\text { Personnel } \\
\text { management } \\
\text { routines }\end{array}$ & $\begin{array}{l}\text { Limited } \\
\text { personnel, no } \\
\text { systemic } \\
\text { routines, needs } \\
\text { based } \\
\text { development }\end{array}$ & $\begin{array}{l}\text { Standardized } \\
\text { work and } \\
\text { skills and } \\
\text { recruitment } \\
\text { processes }\end{array}$ & $\begin{array}{l}\text { Divided } \\
\text { between } \\
\text { headquarter } \\
\text { and } \\
\text { autonomous } \\
\text { divisions } \\
\end{array}$ & $\begin{array}{l}\text { Dependent on } \\
\text { training to } \\
\text { standardize the } \\
\text { skills of its } \\
\text { professionals }\end{array}$ & $\begin{array}{l}\text { Variety and mix } \\
\text { of skills, } \\
\text { openness to } \\
\text { learning and } \\
\text { experimentation }\end{array}$ \\
\hline $\begin{array}{l}\text { Financial } \\
\text { management } \\
\text { routines }\end{array}$ & $\begin{array}{l}\text { Flexible; } \\
\text { emergent }\end{array}$ & $\begin{array}{l}\text { Efficiency } \\
\text { and process } \\
\text { oriented }\end{array}$ & $\begin{array}{l}\text { Autonomous } \\
\text { divisions, } \\
\text { output oriented }\end{array}$ & $\begin{array}{l}\text { Mixed; based } \\
\text { on professional } \\
\text { autonomy }\end{array}$ & $\begin{array}{l}\text { Flexible, not } \\
\text { efficiency } \\
\text { oriented }\end{array}$ \\
\hline $\begin{array}{l}\text { Coordination } \\
\text { routines }\end{array}$ & $\begin{array}{l}\text { Direct } \\
\text { supervision }\end{array}$ & $\begin{array}{l}\text { Standardizatio } \\
\mathrm{n} \text { of work } \\
\text { processes }\end{array}$ & $\begin{array}{l}\text { Standardizatio } \\
\mathrm{n} \text { of outputs }\end{array}$ & $\begin{array}{l}\text { Standardizatio } \\
\mathrm{n} \text { of skills }\end{array}$ & $\begin{array}{l}\text { Mutual } \\
\text { adjustment }\end{array}$ \\
\hline $\begin{array}{l}\text { Capacities } \\
\text { and values }\end{array}$ & $\begin{array}{l}\text { Simple/initial } \\
\text { developments } \\
\text { and changes }\end{array}$ & $\begin{array}{l}\text { Efficiency, } \\
\text { transparency, } \\
\text { accountability }\end{array}$ & $\begin{array}{l}\text { Concentration } \\
\text { of different } \\
\text { focuses }\end{array}$ & $\begin{array}{l}\text { Professional } \\
\text { proficiency }\end{array}$ & $\begin{array}{l}\text { Learning and } \\
\text { complex } \\
\text { innovations }\end{array}$ \\
\hline
\end{tabular}


Table 2: Case study examples mapped to routines, legitimacy and capacity from Karo and Kattel (2016a, 2016b), with inclusion actions

\begin{tabular}{|c|c|c|c|c|c|c|c|}
\hline $\begin{array}{l}\text { Organisation } \\
\text { or unit }\end{array}$ & $\begin{array}{l}\text { Organisation } \\
\text { or unit type }\end{array}$ & Key individual & $\begin{array}{l}\text { Innovation } \\
\text { goals }\end{array}$ & Key routine(s) & Legitimacy & Key capacities & $\begin{array}{l}\text { Inclusive } \\
\text { development actions }\end{array}$ \\
\hline $\begin{array}{l}\text { Municipalities, } \\
\text { provincial } \\
\text { governments } \\
\text { and national } \\
\text { sector } \\
\text { departments }\end{array}$ & $\begin{array}{l}\text { Diversified } \\
\text { machine }\end{array}$ & $\begin{array}{l}\text { Municipal } \\
\text { manager or head } \\
\text { of department }\end{array}$ & $\begin{array}{l}\text { Social or } \\
\text { economic } \\
\text { impact; Public } \\
\text { recognition } \\
\text { for being } \\
\text { innovative }\end{array}$ & $\begin{array}{l}\text { Organisational: } \\
\text { Centralised } \\
\text { bureaucracy, } \\
\text { formalised, specialised } \\
\text { work and division of } \\
\text { labour }\end{array}$ & $\begin{array}{l}\text { Service delivery } \\
\text { extension and } \\
\text { improvement }\end{array}$ & $\begin{array}{l}\text { Political; } \\
\text { Policy }\end{array}$ & $\begin{array}{l}\text { Encourage citizen } \\
\text { feedback and } \\
\text { adjustment }\end{array}$ \\
\hline $\begin{array}{l}\text { Service } \\
\text { delivery } \\
\text { division/ unit }\end{array}$ & $\begin{array}{l}\text { Diversified } \\
\text { machine }\end{array}$ & $\begin{array}{l}\text { Head of division/ } \\
\text { unit }\end{array}$ & $\begin{array}{l}\text { Performance } \\
\text { on target; } \\
\text { Technical and } \\
\text { commercial } \\
\text { sustainability }\end{array}$ & $\begin{array}{l}\text { Coordination: } \\
\text { Standardisation of work } \\
\text { processes; Financial } \\
\text { management: value for } \\
\text { money }\end{array}$ & $\begin{array}{l}\text { Operational } \\
\text { experience/ } \\
\text { understanding; large } \\
\text { user base; Service } \\
\text { delivery extension } \\
\text { and improvement }\end{array}$ & $\begin{array}{l}\text { Policy; } \\
\text { Administrative; } \\
\text { Technical; } \\
\text { Commercial }\end{array}$ & $\begin{array}{l}\text { Extend service } \\
\text { delivery reach (reduce } \\
\text { capital and operational } \\
\text { costs); Improve } \\
\text { service relevance and } \\
\text { citizen relations: } \\
\text { public participation in } \\
\text { planning, delivery } \\
\text { and/or monitoring }\end{array}$ \\
\hline RDI unit & Entrepreneurial & Head of unit & $\begin{array}{l}\text { Service } \\
\text { delivery } \\
\text { improvement; } \\
\text { Develop local } \\
\text { businesses }\end{array}$ & $\begin{array}{l}\text { Coordination: } \\
\text { Communication and } \\
\text { interaction to influence } \\
\text { culture/ processes and } \\
\text { build internal/ external } \\
\text { partnerships; Enrol } \\
\text { political support for } \\
\text { innovation activities; } \\
\text { Coordinate access to } \\
\text { relevant research and } \\
\text { evidence synthesis to } \\
\text { support policy decision- } \\
\text { making; Establish } \\
\text { resourcing and }\end{array}$ & $\begin{array}{l}\text { Association with } \\
\text { research and } \\
\text { technical leaders; } \\
\text { Innovation case } \\
\text { studies; Technical } \\
\text { knowledge on } \\
\text { process improvement }\end{array}$ & $\begin{array}{l}\text { Technical; } \\
\text { Policy }\end{array}$ & $\begin{array}{l}\text { Establish local } \\
\text { innovation forums to } \\
\text { enable marginalised } \\
\text { actor participation; } \\
\text { Encourage user-driven } \\
\text { innovation; Partner } \\
\text { with local CSOs to } \\
\text { innovate on social } \\
\text { issues; Diversify } \\
\text { supplier base }\end{array}$ \\
\hline
\end{tabular}




\begin{tabular}{|c|c|c|c|c|c|c|c|}
\hline $\begin{array}{l}\text { Organisation } \\
\text { or unit }\end{array}$ & $\begin{array}{l}\text { Organisation } \\
\text { or unit type }\end{array}$ & Key individual & $\begin{array}{l}\text { Innovation } \\
\text { goals }\end{array}$ & Key routine(s) & Legitimacy & Key capacities & $\begin{array}{l}\text { Inclusive } \\
\text { development actions }\end{array}$ \\
\hline & & & & $\begin{array}{l}\text { implementation } \\
\text { partnerships with CSOs } \\
\text { and private entities }\end{array}$ & & & \\
\hline $\begin{array}{l}\text { (Local) } \\
\text { Economic } \\
\text { development } \\
\text { unit }\end{array}$ & $\begin{array}{l}\text { Entrepreneurial } \\
\text { machine }\end{array}$ & Head of unit & $\begin{array}{l}\text { Increased } \\
\text { economic } \\
\text { activity; } \\
\text { Reduce } \\
\text { unemployment }\end{array}$ & $\begin{array}{l}\text { Coordination: } \\
\text { Engagement with private } \\
\text { sector on PPPs, business } \\
\text { licensing, incentives; } \\
\text { Openness to engagement } \\
\text { and learning for market } \\
\text { intelligence. }\end{array}$ & Legal and incentives & $\begin{array}{l}\text { Commercial; } \\
\text { Administrative }\end{array}$ & $\begin{array}{l}\text { Facilitate public } \\
\text { participation/ } \\
\text { transparency and } \\
\text { accountability in PPP } \\
\text { processes; Partner } \\
\text { with colleges to } \\
\text { develop relevant skills }\end{array}$ \\
\hline $\begin{array}{l}\text { Procurement } \\
\text { unit }\end{array}$ & Machine & $\begin{array}{l}\text { Supply chain } \\
\text { manager }\end{array}$ & $\begin{array}{l}\text { Minimum } \\
\text { functionality } \\
\rightarrow \text { value for } \\
\text { money }\end{array}$ & $\begin{array}{l}\text { Coordination: } \\
\text { Standardisation of work } \\
\text { processes; Financial } \\
\text { management: Efficiency } \\
\text { and process oriented; } \\
\text { Organisational: } \\
\text { Centralised } \rightarrow \\
\text { decentralised }\end{array}$ & $\begin{array}{l}\text { Efficient processes } \\
\text { and clean audits }\end{array}$ & $\begin{array}{l}\text { Administrative: } \\
\text { transparency, } \\
\text { efficiency, } \\
\text { accountability }\end{array}$ & $\begin{array}{l}\text { Review procurement } \\
\text { approach and } \\
\text { evaluation criteria to } \\
\text { reward innovation } \\
\text { and/or enable supplier } \\
\text { diversification }\end{array}$ \\
\hline $\begin{array}{l}\text { State-owned } \\
\text { enterprises } \\
\text { (SOEs) }\end{array}$ & $\begin{array}{l}\text { Diversified, } \\
\text { professional } \\
\text { machine }\end{array}$ & CEO & $\begin{array}{l}\text { Financial } \\
\text { sustainability; } \\
\text { Economic } \\
\text { impact }\end{array}$ & $\begin{array}{l}\text { Strategic management: } \\
\text { 'Corporate' portfolio } \\
\text { strategy and divisions } \\
\text { with individual } \\
\text { strategies }\end{array}$ & $\begin{array}{l}\text { Procurement; } \\
\text { technical } \\
\text { knowledge; Large } \\
\text { user base }\end{array}$ & $\begin{array}{l}\text { Commercial; } \\
\text { Political; } \\
\text { Policy }\end{array}$ & $\begin{array}{l}\text { Encourage citizen } \\
\text { feedback and } \\
\text { adjustment }\end{array}$ \\
\hline $\begin{array}{l}\text { Service } \\
\text { delivery } \\
\text { division or } \\
\text { business unit }\end{array}$ & $\begin{array}{l}\text { Diversified } \\
\text { machine }\end{array}$ & $\begin{array}{l}\text { Division or } \\
\text { business unit head }\end{array}$ & $\begin{array}{l}\text { Financial } \\
\text { sustainability; } \\
\text { increase reach } \\
\text { and quality of } \\
\text { services; } \\
\text { Mitigate social } \\
\text { and }\end{array}$ & $\begin{array}{l}\text { Personnel management: } \\
\text { Standardisation and } \\
\text { improvement of technical } \\
\text { (engineering) skills incl. } \\
\text { professional registrations } \\
\text { and continuing } \\
\text { professional development. } \\
\text { Some recruitment and }\end{array}$ & $\begin{array}{l}\text { Large pool of } \\
\text { technical skills; } \\
\text { procurement; } \\
\text { operational } \\
\text { experience/ } \\
\text { understanding }\end{array}$ & $\begin{array}{l}\text { Commercial; } \\
\text { Technical; } \\
\text { Policy }\end{array}$ & $\begin{array}{l}\text { Improve SOE- } \\
\text { government customer } \\
\text { feedback and } \\
\text { relations; Increase } \\
\text { reach and quality of } \\
\text { services (reduce } \\
\text { capital and operational } \\
\text { costs) }\end{array}$ \\
\hline
\end{tabular}




\begin{tabular}{|c|c|c|c|c|c|c|c|}
\hline $\begin{array}{l}\text { Organisation } \\
\text { or unit }\end{array}$ & $\begin{array}{l}\text { Organisation } \\
\text { or unit type }\end{array}$ & Key individual & $\begin{array}{l}\text { Innovation } \\
\text { goals }\end{array}$ & Key routine(s) & Legitimacy & Key capacities & $\begin{array}{l}\text { Inclusive } \\
\text { development actions }\end{array}$ \\
\hline & & & $\begin{array}{l}\text { environmental } \\
\text { risks }\end{array}$ & $\begin{array}{l}\text { remuneration flexibility } \\
\text { within guidelines. } \\
\text { Financial management: } \\
\text { value for money }\end{array}$ & & & \\
\hline $\begin{array}{l}\text { RDI } \\
\text { committee(s) or } \\
\text { unit }\end{array}$ & Professional & $\begin{array}{l}\text { Head of } \\
\text { committee or unit }\end{array}$ & $\begin{array}{l}\text { Cost reduction; } \\
\text { increase reach } \\
\text { and quality of } \\
\text { services; new } \\
\text { revenue } \\
\text { streams (IP } \\
\text { royalties, } \\
\text { advisory) }\end{array}$ & $\begin{array}{l}\text { Coordination: Develop } \\
\text { new strategic R\&D } \\
\text { partnerships } \rightarrow \text { Internal } \\
\text { communication and } \\
\text { interaction to influence } \\
\text { culture/ processes; }\end{array}$ & $\begin{array}{l}\text { Intellectual status; } \\
\text { Operational track } \\
\text { record; Innovation } \\
\text { case studies }\end{array}$ & $\begin{array}{l}\text { Technical; } \\
\text { Commercial }\end{array}$ & $\begin{array}{l}\text { Develop innovation } \\
\text { partnerships/ } \\
\text { engagement with } \\
\text { marginalised } \\
\text { municipalities; } \\
\text { Diversify supplier } \\
\text { base by working with } \\
\text { innovation } \\
\text { intermediaries on } \\
\text { 'tech localisation' }\end{array}$ \\
\hline $\begin{array}{l}\text { Procurement } \\
\text { unit }\end{array}$ & $\begin{array}{l}\text { (similar to } \\
\text { Municipalities } \\
\text { and sector } \\
\text { departments } \\
\text { above) }\end{array}$ & & & & & & \\
\hline $\begin{array}{l}\text { Public sector } \\
\text { innovation } \\
\text { intermediaries }\end{array}$ & $\begin{array}{l}\text { Professional- } \\
\text { diversified }\end{array}$ & $\mathrm{CEO}$ & $\begin{array}{l}\text { Service } \\
\text { delivery } \\
\text { impact; } \\
\text { Political } \\
\text { recognition } \\
\text { for leading } \\
\text { innovation }\end{array}$ & $\begin{array}{l}\text { Strategic management: } \\
\text { Planning that is } \\
\text { strategic programming }\end{array}$ & $\begin{array}{l}\text { Access to } \\
\text { innovators and } \\
\text { information, } \\
\text { understanding of } \\
\text { service delivery } \\
\text { context }\end{array}$ & $\begin{array}{l}\text { Policy; } \\
\text { Political }\end{array}$ & $\begin{array}{l}\text { Extend reach of } \\
\text { innovation } \\
\text { programmes }\end{array}$ \\
\hline $\begin{array}{l}\text { Innovation } \\
\text { facilitation } \\
\text { programme or } \\
\text { unit }\end{array}$ & Entrepreneurial & $\begin{array}{l}\text { Programme or } \\
\text { unit lead }\end{array}$ & $\begin{array}{l}\text { New pilot } \\
\text { projects with } \\
\text { users and } \\
\text { replication to } \\
\text { other regions }\end{array}$ & $\begin{array}{l}\text { Coordination: Openness; } \\
\text { Financial management: } \\
\text { Process oriented } \rightarrow \\
\text { flexible; Personnel } \\
\text { management: Needs- }\end{array}$ & $\begin{array}{l}\text { Technology and } \\
\text { innovation process } \\
\text { knowledge/ skills; } \\
\text { Connectedness to } \\
\text { innovators and }\end{array}$ & $\begin{array}{l}\text { Technical; } \\
\text { Policy; } \\
\text { Commercial }\end{array}$ & $\begin{array}{l}\text { Identify opportunities } \\
\text { for incremental/ local } \\
\text { innovation; Facilitate } \\
\text { public sector and }\end{array}$ \\
\hline
\end{tabular}




\begin{tabular}{|l|l|l|l||l|l||l|}
\hline $\begin{array}{l}\text { Organisation } \\
\text { or unit }\end{array}$ & $\begin{array}{l}\text { Organisation } \\
\text { or unit type }\end{array}$ & Key individual & $\begin{array}{l}\text { Innovation } \\
\text { goals }\end{array}$ & Key routine(s) & Legitimacy \\
\hline $\begin{array}{l}\text { Technological } \\
\text { support } \\
\text { programme or } \\
\text { unit }\end{array}$ & Entrepreneurial & $\begin{array}{l}\text { Programme or } \\
\text { unit lead }\end{array}$ & $\begin{array}{l}\text { Adoption of } \\
\text { strategies or } \\
\text { policies on } \\
\text { technology } \\
\text { procurement } \\
\text { and } \\
\text { implementation } \\
\text { development actions }\end{array}$ & $\begin{array}{l}\text { (similar to above) } \\
\text { social innovation } \\
\text { involving CSOs } \\
\text { Understanding of }\end{array}$ & $\begin{array}{l}\text { information; } \\
\text { context. }\end{array}$ & $\begin{array}{l}\text { Identify ways in } \\
\text { which technology may } \\
\text { increase inequality or } \\
\text { harm to vulnerable; } \\
\text { Ensure participation in } \\
\text { technology decision- } \\
\text { making by non- } \\
\text { technical individuals } \\
\text { and groups }\end{array}$ \\
\hline
\end{tabular}

